\title{
The Problematic Forms of Nominalization in English: Gerund, Verbal Noun, and Deverbal Noun
}

\author{
Inam Ismael Taher ${ }^{1}$ \\ ${ }^{1}$ College of Basic Education, Diyala University, Iraq \\ Correspondence: Inam Ismael Taher, College of Basic Education, University of Diyala, Diyala, Iraq. E-mail: \\ inaam.tahir@yahoo.com
}

Received: January29, 2015

Accepted: February 26, 2015

Online Published: March 16, 2015

doi:10.5430/elr.v4n1p30

URL: http://dx.doi.org/10.5430/elr.v4n1p30

\begin{abstract}
This paper addresses a problematic issue concerning the three forms of nominalization: gerund, verbal noun, and deverbal noun. These nominals are problematic for two reasons. The first reason is that they mix different degrees of nominal and verbal properties, so the choice of these nominals for certain structure is not easily predictable. The second one is that there are many discrepancies concerning the terminology related to these forms used in linguistic references and studies. The confusing terminology is misleading for the researcher, teachers, and learners.

The terms under investigation have different internal structures, but they share the same nominal functions and distribution within the sentence (subject, object, etc.). The study aims to point out the confusing discrepancies in terminology, the properties of these forms, the similarities and differences between these three forms, and accordingly their categories.
\end{abstract}

Keywords: Category, Derivational suffix, Deverbal noun, Gerund, Inflectional suffix, Verbal noun

\section{Introduction}

Gerund, Verbal noun, and deverbal noun are grammatical terms related to nominals formed from verbs. They are different kinds of nominalization which have different degrees of nominal and verbal properties.

These terms are different in their meaning and structure. The following examples show the internal structures of these grammatical terms:

1. John's refusing the offer was out of anger.

2. John's refusing of the offer was polite.

3. John's refusal of the offer is unjustifiable. gerund

verbal noun

deverbal noun

There are many discrepancies concerning the terminology related to these forms used in linguistic references and studies. These discrepancies lead to confusion for researchers, teachers, and learners (Note 1). The following examples support what has been said:

1. Quirk et al (1985: 1290) state that the verbal nouns can be used with the adjuncts relating to manner, as in (Note 2):

4. Their acting in a nasty manner surprised us.

and it is known that in a nasty manner can be replaced by the adverb of manner nastily:

5. Their acting nastily surprised us.

Then Quirk et al mention that the gerund can be modified by adverbs and the verbal noun by adjectives, as in the following examples (ibid: 1291):

6. Brown's deft painting of his daughter is wonderful.

verbal noun

7. Brown's deftly painting his daughter keeps him out of others.

gerund

Thus, acting in (4) is a gerund not a verbal noun, whereas acting in the following example is a verbal noun because it is modified by an adjective:

8. Their nasty acting makes them out of job. 
2. Crystal (2003: 203) points out that there is uncertainty over the correct label of-ing form in sentences such as

9. It's no use my/me asking her.

Older grammars analyze asking as a gerund or a verbal noun but it would be analyzed in modern grammar as a verb (-ing form).

3. Janigova (2008: 33) points out the differences between the verbal noun and deverbal noun. He states that the verbal nouns have underlying sentence-like structure depending on chomsky's Remarks on Nominalization (1970:187) in which Chomsky shows the difference between the gerundive nominal (gerund) and the derived nominal ( deverbal noun) and he states that gerundive nominals (gerunds not verbal nouns) have underlying sentence - like structures ( see table 1 concerning terminology).

4. The definition of deverbal nouns and verbal nouns are mentioned in the Wikipedia as follows

Deverbal nouns are nouns that are derived from verbs or verb phrases, but that behave grammatically purely as nouns, not as verbs. They are distinct from verbal noun types such as gerunds and infinitives, which behave like verbs within their phrase.

Verbal nouns do not take direct objects as verbs can, and they are modified by adjectives rather than adverbs. They may also be used as count nouns and pluralized. Some authors call these deverbal nouns rather than verbal nouns. In English, such nouns can be formed from verbs with the suffix -ing, that is, they take the same form as the gerund. Examples of such uses are given below:

10. The killing of the president was an atrocious crime.

11. Most verses of the psalm have multiple readings.

In the first definition, the gerund is considered a type of verbal nouns and in the second one the verbal noun is confused with the deverbal noun. It is mentioned that when the verbal nouns are used as count nouns and pluralized they are considered deverbal nouns by some authors. This means that the -ing deverbal noun is a kind of verbal nouns. The site considers the two examples verbal nouns, but in fact, killing is a verbal noun and readings is a deverbal noun.

5. Huddleston (1984) states that the combination of verb-like and noun-like properties of the gerund underlies the traditional characterization of gerunds as verbal nouns. So, the verbal noun has often been treated as a synonym for gerund.

The three terms under investigation are subject to discrepancy in terminology because their categories are fuzzy and controversial especially the gerund and the verbal noun. They have the same external distribution in the sentence with different internal structures. They have something in common morphologically. The gerunds and the verbal nouns are - ing forms of the verb (e.g. Refusing), whereas the deverbal nouns are nouns derived from verbs including -ing forms (e.g. meeting, building, painting) and non-ing forms (e.g. refusal, imitation). Some authors distinguish between these forms but others use the -ing form as a general term to cover all the -ing forms without terminological differentiation: the gerund, the verbal noun, the -ing deverbal noun, and the participle. The -ing participle is excluded in this study because it is not a form of nominalization, but it is mentioned when required. The following terms will be used in this study, for the sake of consistency, regardless the different labels given to these terms by some authors:

gerund

verbal noun

-ing deverbal noun

deverbal noun

The terminological variants used by some authors are shown in the table below: 
Table 1. Terminological Variants

\begin{tabular}{llllll}
\hline Author & gerund & verbal noun & & -ing deverbal noun & deverbal noun \\
\hline Alexander & Gerund & Gerund & & -ing form & \\
Alexiadou & Verbal gerund & Nominal gerund & & \\
Chomsky & Gerundive nominal & mixed nominal & derived nominal & & Derived nominal \\
Close & Gerund, -ing form & & & & Noun \\
Greenbaum & gerund & Verbal noun & & Deverbal noun & Deverbal noun \\
Quirk et al & Gerund & Verbal noun & & Deverbal noun & Deverbal noun \\
Leech\& Svartvic & Nominal -ing participle & -ing form & & \\
\hline
\end{tabular}

\section{Nominalization}

Crystal (1997: 260) defines nominalization as:

1. the process of forming a noun from some other word - class as: redness and refusal.

2. the derivation of a noun phrase from an underlying clause as :

\section{2. a. Her answering of the letter was expected.}

From

\section{b. She answered the letter.}

The first point is related to the deverbal noun and the second one to the verbal noun. The gerund is not included in this definition.

Quirk et al (1985: 1288ff) define nominalization as a noun phrase which has a systematic correspondence with a clause structure. The head of such a noun phrase is normally related morphologically to a verb or to an adjective. They mention three kinds of nominalization: gerund, verbal noun, and deverbal noun.

Gerund and verbal noun are formed by adding (-ing) to the verb with different internal structure as in the following examples respectively:

\section{3. a. Writing the book needs time.}

14. a. The writing of the book made him well known.

\section{b. He wrote the book.}

b. He wrote the book.

The deverbal nouns are derived from verbs either by suffixation or conversion as in the following examples:
15. a. His refusal to help was expected.
16. a. His answer is correct.
b. He refuses to help.
b. He answered the question.

Janigova(2008: 9) points out that nominalization refers to the process of conveying a verb - related meaning by a noun phrase whose underlying structure is clausal. It refers also to the constructions that result from the process.

Trask (2007: 186-187) defines nominalization as any grammatical unit which behaves like a noun or a noun phrase but it is built up from something very different. There are simple and complex kinds of nominalization. He gives the following examples:

\section{7. a. She arrived at ten o'clock.}

b. Her sudden arrival surprised us. Simple nominalization

18. a. Tom and Sally Perkins study volcanoes.

b. Studying volcanoes is dangerous work. Complex nominalization

19. a. Susie smokes.

b. That Susie smokes surprises us. Complex nominalization

Chomsky (1970: 214ff) distinguishes three types of nominalization:

The gerundive nominal, derived nominal, and mixed nominal corresponding respectively to Quirk et al's gerund, deverbal noun and verbal noun. Chomsky gives the following examples:

20. John's refusing the offer was out of anger.

21. John's refusal of the offer is unjustifiable.

22. John's refusing of the offer is polite. gerundive nominal

derived nominal

mixed nominal 
The derived nominals include nominals derived from verbs or from other classes, as adjectives (ibid.):

23. John is eager to please.

24 John's being eager to please is remarkable.

25. John's eagerness to please makes him happy. adjective

gerundive nominal (gerund)

derived nominal (deverbal noun)

Chomsky refers to the third type of nominalization as mixed nominals because they behave as derived nominals and gerundive nominals.

Brown and Miller (1980 back cover) use the three forms of nominalization in the following sentence:

An understanding of the concepts used in any full description of language is crucial for assessing the strengths and weakness of formal grammars.

\subsection{Gerund}

The gerund is the -ing form of the verb when it has the function of a noun phrase (Close 1975: 79). It is traditionally seen as nominalization and this means that its internal syntax may be clausal and its external syntax is that of a noun phrase (De Smet, 2010: 1). So, it is a name given to the mixture of nominal and verbal characteristics in -ing form (Quirk et al, 1985:1291 -1292). Consider the difference between the following sentences:
26. Standing here all day, I see some very strange people.
Participle
27. I am standing here all day.
Participle
28. Standing (here all day) makes me very tired.
Gerund

The gerund is always confused with the present participle, which occurs outside nominal positions.

The structure that contains a gerund is given different labels: the nominal -ing clause, nominal -ing participle clause, and gerundive (or gerundival) clause (Quirk et al, 1985: 1063, 1064 note (c)). The gerundive clause can be the subject, subject complement, object, object of a preposition, as in the following examples respectively:

29. Watching television keeps them out of mischief.

30. The problem is getting something done about the cheap imports. (LGSWE) (Note 3)

31. He enjoys playing practical jokes.

32. No one could rely on his going to bed early last night. (LGSWE)

The gerund has the following properties mentioned by Pullum (1991, cited in Kim, 2008: 326) among others:

1. It can be modified by an adverbial

33. Brown's deftly painting his wife is wonderful.

2. It can contain the negating particle not

34. Pat's not having called for a week yet bothered us.

3. It allows auxiliaries, so it may have a perfect or/and passive forms:

35. John's having criticized the play annoyed us.

4. It can take an object

36. Mary's suddenly giving him a book caused uproar. (Beker, 2005:3-4)

37. You like my giving Maria food.

5. The subject of the gerund can be a genitive / possessive or an accusative NP (Note 4)

38. He insisted on $\boldsymbol{m y} / \boldsymbol{m} \boldsymbol{e}$ reading it. (Thomson and Martinet (1986: 231))

These gerund constructions as a whole have the distribution and behavior of noun phrases within the matrix clause that they occur in.

Thomson and Martinet $(1986: 228,231)$ point out that the gerund is used when an action is considered in a general sense, as in:

39. Reading French is easier than speaking it.

40. He dislikes working late.

41. Her hobby is painting. 
42. "Feeling gratitude and not expressing it is like wrapping a present and not giving it." (William Arthur Ward) (Note 5)

The gerundive clause may refer to a fact or to an action as in the following respectively (Quirk etal 1985:1064):

43. Your driving a car to New York in your condition disturbs me.

44. Your driving a car to New York took longer than I expected.

\section{Concerning the categorical status of the gerund, there is a conflict between grammarians about it.}

The characteristics of gerund indicate that it has mainly verbal characteristics and it can be considered syntactically a verb (Greenbaum, 1992). Some grammarians claim that gerunds are lexical categories that are simultaneously nouns and verbs but Baker (2005:42) argues against this idea. He states that gerunds are fusions of a true verb and a distinct nominal inflection. Being a verb, it has the ability to take direct NP complements and this property is primarily a matter of internal structure, whereas being a nominal involves the ability to function as an argument as the subject or object of a sentence and this property is primarily a matter of external distribution (ibid.:5-6).

Quirk et al (1985:1064note(c)) point out that the verb in the gerundive clause is called a gerund, then they state that the verbal noun is used only for the gerund class of nouns in -ing (ibid.1521). They consider the gerund a verb and a noun.

Biber et al (1999: 67) consider the mixed construction (gerund) as a particular area of difficulty because this construction has nominal and verbal properties. For example, in There is no denying it, the determiner no suggests that denying is a noun, while the following object it suggests that it is a verb. They argue that the -ing form should be considered $\boldsymbol{a}$ verb in such cases since the verb category applies more generally to -ing words.

Aarts (2006: 213 cited in De Smet, 2010: 3) believes that the syntax of the gerund can be reduced to the intersection between two categories: verbs and nouns and he suggests that there is no need to recognize a category of 'gerund' in addition to nouns and verbs.

Huddleston and Pullum (2002cited in De Smit, 2010: 2) argue that English gerunds can be conflated with English present participles into a single category of gerund-participial. They reject the view of traditional grammars, which has kept gerunds and participles apart because the former is akin to noun phrases and the latter to adjectival or adverbial phrases.

The category of gerund-participial is misleading because the gerund and the -ing participle are verbs but the former occurs in nominal positions and the latter in adjectival and adverbial positions. The -ing suffix of the gerund is nominal not verbal and it is inflectional not derivational because it is considered a verb by form and a nominal by position.

\subsection{Verbal Noun}

Quirk et al (1985:1291) define verbal noun as an abstract noncount noun of the kind that can be formed from verbs by adding -ing and inserting $\boldsymbol{o f}$ before the noun phrase that corresponds to the subject if the object is not expressed:

45. The painting of Brown is wonderful.

46. The writing of Smith is impressive.
$=$ Brown paints

$=$ Smith writes

and before the noun phrase that corresponds to the object if it is expressed:

\section{Their polishing of the furniture is noticeable.}

48. The writing of novels (by Smith) is impressive.
$=$ They polish the furniture

$=$ Smith writes novels.

The verbs in such examples are dynamic items and they are nominalized to see the actions as static things (Quirk and Greenbaum, 1973: 21). Thus, a verbal noun is primarily a kind of noun, not a kind of verb (Huddleston, 1984).

Crystal (1997: 410) defines verbal noun as "a noun which is similar in form or meaning to a verb as smoking".

This definition is general and can be applied to gerund, verbal noun, and (-ing) deverbal noun, and smoking cannot be considered a verbal noun unless it is used in a sentence.

The verbal noun has the following properties mentioned by Pullum (1991, cited in Kim: 326) among others:

1. It takes of- construction

49. His acting of the part of Othello was distinguished by a breadth and grandeur that placed it far beyond the efforts of other actors. (Note 6) 
2. It can be modified by an adjective

50. Brown's deft painting of his daughter is wonderful.

3. It can be preceded by a determiner

51 . The crying of the child was very noisy.

4. It cannot contain an auxiliary

52.* Brown's having painted of his wife is wonderful.

5. The subject of the verbal noun is a genitive NP

53. Brown's painting of his wife is wonderful.

Concerning the categorical status of the verbal noun, almost most of the grammarians agree that it is a noun. The properties of the verbal noun indicate that it belongs to the noun category, and it is always abstract and noncount noun.

Trask (2006) points out that although the verbal noun is derived from a verb, it is strictly a noun and it exhibits nominal properties: it takes determiners like the and this, it permits adjectives (not adverbs), and it permits following prepositional phrases (not objects).

Biber et al (1999:67) suggest that the -ing form preceded by a determiner and followed by of- phrase is a noun. This means that the verbal noun banning in the phrase The banning of some chemicals is a noun. Biber et al prefer using -ing form instead of the term verbal noun.

The -ing suffix in the verbal noun can be considered a nominal derivational suffix which is a homophone of the verbal inflectional suffix (-ing vb) mentioned by Stageberg (1981: 92) in addition to the other homophone which is the nominal derivational suffix (-ing nm) related to the deverbal nouns. (Note 7)

\subsection{Deverbal Nouns}

Deverbal nouns are nouns derived from verbs, so they are fully nominalized as pure common nouns with no verbal features but they are related morphologically to verbs. They are derived from verbs either by conversion as attempt or suffixation as destruction. They also include nouns ending in -ing that do not have verbal force as building in The building was empty (Greenbaum, 1992).

The suffix (-ing) combines with the verb to form either abstract nouns as driving or concrete nouns as building (Quirk \& Greenbaum, 1973:438) (Note 8).

Stageberg (1981: 97) mentions that the nominal derivational suffix (-ing $\mathrm{nm}$ ) is a homophone of the verbal inflectional suffix (-ing vb) as in: meeting, weddings, and readings, which is the (-ing) deverbal noun in Quirk et al's terms.

Quirk et al (1985: 1550f) point out that nouns derived from verbs by suffixation are either concrete or abstract. They classify deverbal nouns semantically according to the affixes attached to the verbs into:

1. concrete count nouns with a personal reference, as teacher, actor, assistant, and employee.

2. concrete count nouns referring to what results from the action of the base, as building, opening, filling

3. concrete noncounts, as equipment

4. abstract noncount nouns denoting the action expressed by the base, as breakage, coverage, wastage.

5. abstract noncounts denoting the process or state of, as exploration, ratification, driving

6. abstract noncounts denoting the action or result of, as refusal, revival, dismissal

7. count nouns denoting the product of , the institution produced by, as foundation, organization

Taylor (2001: 242) states that deverbal nouns may be categorized semantically according to what facet of the process they denote, that is, what facet of the process is construed as a thing.

Not all verbs have corresponding abstract deverbal nouns (Quirk et al 1985: 1289f). For example, the verb lie has no abstract deverbal noun but it has the agential deverbal noun liar. In such cases, the verbal noun lying is used to express the process of not telling the truth:

\section{Lying is common.}

Some verbs have no corresponding abstract deverbal nouns but their synonyms have abstract deverbal nouns such as 
the verbs fire and dismiss (ibid.):

55. The firing of William was a mistake.

56. The dismissal of William was a mistake.

The categorical status of deverbal nouns (-ing and non-ing deverbal nouns) is obvious because their properties reveal their noun status clearly. Some nouns have concrete meaning, in referring to objects with singular and plural forms as building(s); others have abstract meaning as arrival.

\section{Comparative Remarks}

\subsection{Verbal Nouns vs. Deverbal Nouns}

It is to be mentioned that not all the kinds of deverbal nouns mentioned above can be used in contrast with the verbal noun. It depends on the meaning of the deverbal noun.

Consider the following examples in which the verbal noun teaching cannot be used in contrast with the deverbal noun teacher:

57. a. He teaches English.

b. His teaching of English is good.

c. ${ }^{*}$ His teacher of English is good.

Whereas in the following examples the verbal noun exploring is used in contrast with the deverbal noun exploration:

58. His exploring of the mountain is taking a long time.

59. His exploration of the mountain took three weeks.

Chomsky (ibid. 214-215) states that the verbal nouns behave as deverbal nouns in having the internal structure of a noun phrase because the possessive subject of both can be replaced by a determiner as in:

60. a. John's refusal of the offer is unjustifiable. deverbal noun

b. The refusal of the offer is unjustifiable.

61. a. John's refusing of the offer is polite. verbal noun

b. The refusing of the offer is polite.

Quirk et al show the following differences between the verbal and deverbal nouns:

1. They differ in their acceptance of modification by prepositional phrases (ibid.: 1290). The verbal nouns can be used with the adjuncts relating to duration, manner, or cause. Using such adjuncts with deverbal nouns seems to be awkward. Compare the following structures:

62. Their arriving for a month is expected.

but not

63. *Their arrival for a month is expected.

The deverbal noun arrival might be described as a mere record of an action rather as description of the action itself (ibid):

64. The arrival took place on Thursday.

2. The difference between the verbal and deverbal nouns can be captured in their aspectual essence. The deverbal noun refers to the complete action as a whole event whereas the -ing verbal noun is not remote from the conduct of the action itself (ibid.1985: 1551note). The following examples show this difference:

65. His exploring of the mountain is taking a long time.

66. His exploration of the mountain took/ will take three weeks.

3. They differ in terms of explicitness. The use of the verbal noun makes the sentence more explicit (ibid 1289):

67. Lanzarotti was disappointed of the reviewers' hostile criticizing of his play.

68. Lanzarotti was disappointed of the reviewers' hostile criticism of his play.

4. In the following examples, the deverbal noun can be replaced by concrete count nouns as pictures or photos, and the verbal nouns can be replaced by abstract noun as representation (ibid.: 1290f). 
69. Brown's paintings of his daughter are nice.

70. Brown's deft painting of his daughter is wonderful. deverbal noun

verbal noun

Verbal and deverbal nouns are different functionally in that verbal nouns keep their verbal characteristics whereas deverbal nouns operate as autonomous common nouns (Jagger, 2001: 285).

Chomsky describes the verbal noun as clumsy when a deverbal noun also exits (1970: 215), as in:

71. John's refusal of the offer is unjustifiable.

72. John's refusing of the offer is surprising.

Trask (2006) confuses the verbal noun with the deverbal noun. He points out that although the verbal noun is derived from a verb, it is strictly a noun, and it exhibits nominal properties: it takes determiners like the and this, it permits adjectives (not adverbs), it permits following prepositional phrases (not objects), and it can be pluralized if the sense permits. So, it seems that Trask confuses the verbal noun with the deverbal noun because the verbal noun cannot be pluralized.

73. In football, the deliberate tripping of an opponent is a foul.

\subsection{Gerund vs. Verbal Noun}

The gerund and the verbal noun are similar in being the -ing form of the verb.

The gerund is different from the verbal noun in that the possessive subject of the former cannot be replaced by a determiner whereas the possessive subject of the latter can be replaced by a determiner (Chomsky: 1970:214).

74. a. John's refusing the offer is out of anger.

b. * The refusing the offer is out of anger.

75. a. John's refusing of the offer is polite.

b. The refusing of the offer is polite.

The differences between the gerund and the verbal noun according to Quirk et al (1985:1291) are explained in the following examples:

76. Brown's deftly painting his daughter makes her happy.

Gerund

77. Brown's deft painting of his daughter is wonderful.

verbal noun

a. With the gerund, the adverb deftly is used and the noun phrase his daughter is used directly after painting.

b. With the verbal noun, the adjective deft and $\boldsymbol{o f}$-phrase are used.

c. The gerund and the verbal noun can be used alone or preceded just by a genitive noun phrase. Then, the construction is syntactically ambiguous, as in:

78. They liked our singing.

79. My hobby is swimming.

80. I hate lying. (ibid.1065)

If the object is expressed or the objective is used, the-ing form is understood as a gerund:

81. They liked our singing folk songs.

82. They liked us singing.

Chomsky (ibid.) points out that gerunds behave as verbal nouns in not permitting adjective insertion as in:

83. a. * John's sudden refusing the offer was out of anger. gerund

b. * John's sudden refusing of the offer is surprising. verbal noun

Chomsky does not mention a justification for not permitting adjective insertion with verbal nouns. In this point, he is different from Quirk et al who accept the occurrence of the adjective with the verbal noun because it has the properties of nouns.

Quirk et al (ibid.) show the difference in meaning between gerund and verbal noun in terms of action and mode interpretation 
The use of the gerund allows action interpretation, and the use of verbal noun allows mode interpretation, as in the following examples respectively:

\section{I warned him against driving fast. \\ 85. I warned him against fast driving.}

The naked-ing form, where an ing- form occurs without any of the clear noun criteria or verb criteria in its context, constitutes the biggest problem in distinguishing nouns from verbs (Biber et al, 1999:67) (Note 9). For example, the -ing form checking in the following sentence is either a noun (deverbal noun) or a verb with a nominal function (gerund)

86. The matter needed checking.

This problem can be solved by expanding the sentence into:

87. The matter needed checking carefully. gerund

or

88. The matter needed careful checking. $\quad$ verbal noun

\subsection{Gerund vs. Deverbal Noun}

The main formal difference between the gerund and the deverbal noun is that the gerund has one form, which is the -ing form, whereas the deverbal noun has different forms including the ing form. Syntactically, the gerund is a verb with a nominal function whereas the deverbal noun is a pure noun.

Chomsky (1970: 187ff) distinguishes between gerunds and deverbal nouns according to the following criteria:

1. The productivity of the process in question

2. The generality of the relation between the nominal and the associated proposition

3. The internal structure of the nominal phrase

These criteria are explained in the following table:

Table 2. Chomsky's Criteria

\begin{tabular}{lll}
\hline \multicolumn{1}{c}{ Criterion } & \multicolumn{1}{c}{ Gerund } & \multicolumn{1}{c}{ Deverbal Noun } \\
\hline $\begin{array}{l}\text { The productivity of the process in } \\
\text { question }\end{array}$ & $\begin{array}{l}\text { can be formed fairly freely from } \\
\text { propositions of subject-predicate } \\
\text { form }\end{array}$ & $\begin{array}{l}\text { cannot be formed freely from } \\
\text { propositions of subject-predicate } \\
\text { form (restricted) } \\
\text { has quite varied and idiosyncratic } \\
\text { relations }\end{array}$ \\
$\begin{array}{l}\text { The generality of the relation } \\
\text { between the nominal and the }\end{array}$ & $\begin{array}{l}\text { haste regular relation } \\
\begin{array}{l}\text { The internal structure of the } \\
\text { nominal phrase }\end{array}\end{array}$
\end{tabular}

This can be explained below with examples:

1. Gerund can be formed fairly freely from propositions of subject-predicate form, whereas deverbal noun cannot be formed freely from propositions of subject-predicate form (restricted). This can be explained in the following examples:

89. John amused the children with his stories.

90. John's amusing the children with his stories makes them happy.

91. *John's amusement the children with his stories makes them happy.

2. Gerunds have quite regular relation with the associated verbs, whereas deverbal nouns have quite varied and idiosyncratic relations with their base verbs. Consider, for examples, the derived nominals laughter, marriage, belief, and qualifications with their ranges of meaning and varied semantic relations to the base verbs.

3. Gerund does not have the internal structure of a noun phrase, whereas derived nominal has the internal structure of a noun phrase. For example, the gerundive cannot be preceded by the definite article nor by an adjective, as in the following examples: 
92. a. The proof of the theorem is long.

but not

b. *The proving the theorem is long.

93. a. John's unmotivated criticism of the book is found on page 5.

but not

b. * John's unmotivated criticizing the book is found on page 5 .

\section{Conclusions}

The research has arrived at the following conclusions:

1. The gerund, verbal noun, and deverbal nouns are distinct terms and they are different in structure and meaning.

2. There are many discrepancies concerning the terminology of the three forms of nominalization in question.

3. Gerunds are fusions of a true verb and a distinct nominal inflection. They are verbs by form and nominals by position.

4. Verbal nouns belong to the noun category. They are abstract noncount nouns with one form and one meaning. They are nouns by form and nominals by position.

5. Deverbal nouns have their own entries in the lexicon with different kinds and meanings. They are considered autonomous common nouns.

6. The -ing suffix in the gerund is nominal and inflectional, whereas in the verbal noun and -ing deverbal noun it is nominal and derivational.

\section{Acknowledgement}

I would like to express my thanks to the two anonymous reviewers and the editors of this journal for their useful comments on the first version of this paper. I am grateful to Prof. Richard Nordquist, the about.com Guide to Grammar \& Composition for his informative reply to my message. I also thank the two anonymous reviewers in Iraq for their comments on the original form of the paper. I have re-written the whole paper with new perspective.

\section{References}

Alexander, L.G. (1988). Longman English Grammar. England: Longman group.

Alexiadou1, Artemis. (2013). "Nominal vs. Verbal -ing Constructions and the Development of the English Progressive". Journal of English Linguistics Research Vol. 2, No. 2, 126-140. http://dx.doi.org/10.5430/elr.v2n2p126

Aarts, Bas. (2006). Syntactic gradience: The nature of grammatical indeterminacy. Oxford: Oxford University Press.

Baker, Mark. (2005). "On Gerunds and the Theory of Categories". Retrieved from www.rci.rutgers.edu/ mabaker/gerunds\&cattheory.pdf. .

Biber, D., Johansson, S. , Leech, G., Conrad, S. , \& Finegan E. (1999). Longman Grammar of Spoken and Written English. England: Pearson Education Limited.

Brown, E.K. \& Miller, J.E. (1980). Syntax: A Linguistic Introduction to Sentence Structure. London: Hutchinson Group.

Chomsky, Noam. (1970). "Remarks on Nominalization" in Jacobs, R. A. and P. Rosenbaum (eds.), Readings in English Grammar. Waltham, Mass: Ginn and Company.

Close, R.A. (1975). A Reference Grammar for Students of English. London: Longman group.

Crystal, David. (1997). A Dictionary of Linguistic and Phonetics. Oxford: Blackwell.

Crystal, David. (2003). The Cambridge Encyclopedia of The English Language. Cambridge: Cambridge University Press.

De Smet, Hendrik. (2010). English -ing clauses and their problems. The Structures of Grammatical Categories, Research Foundation-Flanders University of Leuven. Retrieved from https://lirias.kuleuven.be/.../English+ing-clauses+and+th...

Deverbal Noun. (2014). In Wikipedia, the free encyclopedia. Retrieved from http://en.wikipedia.org/wiki/Deverbal_noun 
Greenbaum, Sidney. (1992). The Oxford Companion to the English Language. Oxford: Oxford University Press. Retrieved from http://grammar.about.com/od/tz/g/verbalnounterm.htm

Huddleston, R. D. (1984). Introduction to the Grammar of English. Cambridge: Cambridge University Press. Retrieved from http://grammar.about.com/od/tz/g/verbalnounterm.htm

Huddleston, Rodney \& Geoffrey Pullum. (2002). The Cambridge grammar of the English language. Cambridge: Cambridge University Press.

Jagger. Philip. (2001). Hausa: verbal and deverbal nouns, and infinitives. John Benjamins Publishing Company .

Janigova, Slavka. (2008). Syntax of -ing forms in legal English. Berlin: Peter Lang Publication. Retrieved from https://books.google.com/books?isbn=3631574703.

Kim, Yong-Beom.(2008). Distributional Properties and Endocentricity of English Gerunds. Retrieved from www.aclweb.org/anthology/Y/Y01/Y01-1030.pdf .

Leech, G,. \& Svartivk, J. (1994). A communicative Grammar of English . London : Longman.

Pullum, G. (1991). English Nominal Gerund Phrases as Noun Phrase with Verb-Phrase Heads, Linguistics29, 763-799.

Quirk, R., \& Greenbaum, Sidney. (1973). A University Grammar of English. England: Longman Group.

Quirk, R., Greenbaum, S., Leech, G., \& Svartvic, J. (1985). A Comprehensive Grammar of the English Language. London: Longman.

Stageberg, N. C. (1981). An Introductory English Grammar. New York: Holt, Rinehart and Winston.

Taylor, J. R. (2001). Possessives in English. Oxford : Oxford University Press.

Thomson, A.J. \& Martinet, A.V. (1986). A practical English Grammar. Oxford University Press.

Trask, R.L. (2006). Mind the Gaffe!. Harper. Retrieved from http://grammar.about.com/od/tz/g/verbalnounterm.htm.

Trask, R.L. (2007). Language and Linguistics: The Key Concepts. .New York: Rotledge.

Verbal Noun. (2014). In Wikipedia, the free encyclopedia Retrieved from http://en.wikipedia.org/wiki/verbal_noun.

\section{Notes}

Note 1. The researcher is a college instructor and through her teaching English she finds that these terms are confusing for learners.

Note 2. Some examples concerning the three forms of nominalization mentioned in this paper are not complete sentences because they just show the structures of the noun phrases or the nominals. Chomsky and Quirk et al use these structures in their works mentioned in this paper. The researcher has completed these examples.

Note 3. This example is from Longman Grammar of Spoken and Written English (LGSWE).

Note 4. There is a dispute about the use of a genitive/ possessive or accusative form with the gerund. Crystal (2003: 203) states that older grammars use the possessive pronoun (my, etc.) or the genitive form of a noun (John's) before the gerund. Close (1975: 80) states that when the accusative form is used, the -ing form is a participle not a gerund, as in: I'll never forget him imitating the head master, and it could be expanded to: when he is imitating .

Note 5. This example is from http://grammar.about.com/od/fh/g/gerundterm.htm.

Note 6. This example is from http://grammar.about.com/od/tz/g/verbalnounterm.htm.

Note 7. The inflectional suffix (-ing) does not change the part of speech whereas the derivational suffix (-ing) changes the part of speech.

Note 8. Since that a verbal noun and a deverbal noun can sometimes have identical forms (-ing form) as meeting, painting, reading, and building, so this may be confusing. For example, Quirk et al (1985:1290) consider sightings as a verbal noun instead of a deverbal noun.

Note 9. Biber et al(1999) do not prefer using gerund and verbal noun. They prefer using verb clause instead of gerund construction and noun phrase instead of verbal noun construction. 